\title{
Implementation of The Psychowriting Methods to Improve Linguistic Intelligence for Children in the Field of Writing Interest
}

\author{
Muhsin Kalida ${ }^{1}$, Yahya AD $^{2}$ \\ ${ }^{1}$ Universitas Islam Negeri Sunan Kalijaga, Yogyakarta, Indonesia \\ ${ }^{2}$ Universitas Islam Negeri Raden Intan, Lampung, Indonesia \\ yahyaad@radenintan.ac.id
}

Submitted: 2020-10-26, Revised: 2020-11-26, Accepted: 2020-11-28

\begin{abstract}
Increasing children's intelligence requires strategies so that children have the habit of reading and writing things. One strategy that can be used is psychowriting. The purpose of this study was to increase the spirit of children with literacy to have enthusiasm for writing and interest in reading using the psychowriting method. This research is field research with a qualitative descriptive analysis approach. Data collection methods, using observation, interviews and documentation. The results of this study indicate that the implementation of psychowriting methods to improve linguistic intelligence for children is: a) preparation, b) memory strength test, c) presenting the closest and fastest idea, d) creating an atmosphere, e) implementing creative learning, and f) follow-up.
\end{abstract}

Keywords: Linguistic; Psychowriting Method; Writing Interest

(C) 2020 KONSELI: Jurnal Bimbingan dan Konseling (E-Journal)

\section{Introduction}

The Program for International Student Assessment (PISA), in 2015-2016, released the results of an investigation that the literacy level of the Indonesian people was ranked 62 out of 70 countries (Group, 2016). Indonesia as a country with the largest Muslim population in the world, this data is very contrary to the beliefs of Muslims. Allah SWT said in QS. Al-Alaq: 15 , which is written in a fairly clear sentence, namely Iqra '(read!) And al-qalam (write it down). This shows that as Muslims, we must always study, this can be done by reading and writing.

The assumption is that the basic literacy culture of Indonesian children is low, due to the lack of reading traditions and the low interest in reading. This is by the research that explains the low literacy culture is caused by a lack of individual reading interest (Nurdin, 2019). Whereas by reading, individuals will have good skills in writing, this will become a habit in the individual. The results of the study explained that by reading students will be skilled in writing; this will unwittingly become a habit in daily activities (Jasni \& Atmazaki, 2020; Mantasiah, Juffri, \& Yusri, 2017). Writing is a skill that is acquired because of habit, which is closely related to reading habits.

Individuals produce good writing, of course, have good reading activities, by reading a lot of new vocabulary that individuals get so that individuals can write things that they want to express in clear words (Maryani, Ichsan, \& Khairunnisa, 2017). Writing problems are basic literacy and one of the studies in linguistic intelligence that children should have. Reading really helps children to write down what is on their mind easily; this can be used as a method so that individuals can express themselves (Castles, Rastle, \& Nation, 2018; Orr, Smith, Arbour-Nicitopoulos, \& Wright, 2020).

Reading and writing is a language which is a communication tool that cannot be separated in everyday human life. Reading and writing make it easier to obtain, understand, and respond to information (Fitriani, 2014). Language is the main tool for communicating in children's lives, both individually and in groups. Individually writing is a tool for expressing one's ideas and ideals, and collectively language is a tool for interacting with others. Language skills are divided into four aspects, namely a) listening aspects, b) speaking, c) reading, and d) writing (Subandiyah, 2017). Basically, these four aspects are a unity that is difficult to separate in 
communicating, especially for children. These four aspects have a strong correlation so that someone can communicate effectively, both orally and in writing. Writing is a critical competency in language and communication (Komaladewi \& Rodiyana, 2020). The ability to write is the main asset for children in meeting the needs of literacy and linguistic intelligence. Writing can hone the development of children's knowledge, convey ideas and ideas to others through writing.

The ability to write is an impact and a reflection of the success of language learning (linguistics), both oral and written, but unfortunately, learning writing skills is still not optimal, because it has not received more attention, the weakness of the writing learning system, both informal and non-formal educational institutions. Formal or informal. Even though the implementation of writing competency learning in class affects the achievement of a learning goal, therefore, if the learning process with creation, innovation and fun will be able to excite children's interest in writing, this is what makes the author interested in researching the Implementation of Psychowriting Methods to Improve Linguistic Intelligence for Children in the Field of Writing.

\section{Methods}

This research is field research; the type used in this research is descriptive qualitative; the approach used is the phenomenological approach. The focus of this research is the stages of implementing the psychowriting method in improving linguistic intelligence for children in the field of writing interest. This research was conducted in eight cities in Indonesia, namely in the Enrekang (South Sulawesi), Cirebon (West Java), Pringsewu (Lampung), Ogan Komering Ulu, Sukamara (Central Kalimantan), Sleman (DIY), Magetan and Tulungagung (Java East). The subjects in this study were teachers, students and community leaders related to the implementation of the psychowriting method. The data technique used three techniques, observation, interview and documentation. The data obtained were then analyzed reductively and editically since the data was carried out. Some of the things done in data analysis include reducing data, presenting data, pulling and testing data validity. Meanwhile, to test the validity and validity of the data, using two methods, namely the addition of participatory observation control, and b) using the triangulation method of techniques and sources, to understand the understanding of the data obtained.

\section{Results and Discussion}

After making data reduction, it was found that psychowriting is a holistic method with a multidimensional approach to good creative learning. There are six steps in implementing the psychowriting method to improve linguistic intelligence in the field of writing for children, namely: a) preparation, b) memory strength test, c) presenting the closest and fastest idea, d) creating a mood, e ) implementation of creative learning and f) follow-up.

Learning is a process of interaction between students and teachers and learning resources in a learning environment to achieve the planned learning objectives. The actions taken by the teacher in the classroom are not all a learning process. Learning indicators are changes in behaviour. The learning process is said to be successful if it results in behavioural changes in individuals (Dlouhá, Barton, Janoušková, \& Dlouhý, 2013; Riemer, Frommel, Layher, Neumann, \& Schrader, 2017; Wu et al., 2020). Psychowriting is a method of an approach to learning that is associated with writing skills with psychology through different special treatments for each personality.

Psychowriting can become a medium in improving writing competence and developing characters based on psychology (Laila \& SODIQ, 2018). Theoretically, the relationship between writing skills and psychology is then called the psychology of writing or psychowriting. Psychowriting is essentially a representation of parts of language expression. 
Writing is expressing in writing, ideas, ideas, opinions, thoughts and feelings. The written language contains ideas or thoughts, so it cannot be mastered without continuous practice.

Writing is a form of expression of the soul (Rampung, 2017; Shah, 2016). The expression of the soul is based on four reasons a person has to write, namely: a) humans are created to have the ability as a homo scriptor with four language abilities (listening, speaking, reading, and writing); b) through writing, one can express the heart/soul explicitly and implicitly; c) someone who can write well has good prestige; and d) through writing one can be successful. Simply put, to improve a person's writing skills, he must have the will to write.

Psychowriting as an approach to writing competence is a process of interaction between teachers and students, trainers and workshop participants, tutors and learning citizens, with the rules of the learning process to improve writing skills. The rules for this learning process include a) The learning objective is something to be achieved in a learning process; b) The learning method is a set of plans that contain a series of activities designed to achieve teaching goals; c) Learning media is a tool used as a channel to convey a message or information, from a source (resource) to the recipient; and d) Learning evaluation is a systematic process to determine or make decisions to what extent teaching goals are achieved (Nadlir, 2013; Susilana \& Riyana, 2008).

Linguistic Intelligence, namely the ability to use words effectively, both orally and in writing. Linguistic intelligence in the study of psychology is often called word smart, or word smart, in this case, the emphasis is on words, sentences or language, both spoken and written. Human intelligence is divided into eight intelligences, namely: a) linguistic intelligence (word smart); b) logical intelligence - mathematics; c) physical intelligence; d) spatial-visual intelligence; e) intrapersonal intelligence; f) musical intelligence; g) naturalist intelligence; and h) spiritual intelligence (Gardner, 2006; Moran \& Gardner, 2018). This intelligence does not stand alone, but sometimes there is an integration between one intelligence and another. As in this research study, it is oriented to improve linguistic intelligence, especially about writing interest.

Writing interest is a feeling of preference and interest in writing activities without being asked. The stronger or closer the relationship, the greater the interest. Interest in writing is not carried from birth but is acquired later (Ernis, 2019; Wardiah, 2017). Interest in something is learned and influences the acceptance of new interests. Writing interest is a constant tendency to pay attention to and remember some activities which are manifested in writing.

As an approach in the discipline of education, namely creative learning, especially to increase the interest in writing for children, psychowriting method in its implementation means a holistic method based on a psychological approach, to stimulate an increase in writing interest for the child. So it is right to say that psychowriting method is a method for self-development that not only develops writing interest but also reading interest, with the hope of becoming a writing habit and reading habit.

The purpose of learning using psychowriting is to increase writing potential. In detail, psychowriting aims to help children understand how to express language in written form, encourage children to express themselves freely in written language, help use appropriate and harmonious forms of language in written expressions (Ahmadi, Sodiq, Setiawan, Pratiwi, \& Hariyati, 2019; Wahyuni, 2017). Also, in more detail, the purpose of learning writing skills through the psychowriting method for children is to enrich vocabulary, train to generate new thoughts, feelings and mental expressions, train to describe experiences, and help master language regularly.

There are several important components in the implementation of the psychowriting method, namely the existence of a trainer/psych writer, participants, learning materials, learning media and evaluation (Barak \& Miron, 2005). A trainer in psychowriting is a teacher who provides direction or material; participants are students. Learning material is an important 
learning component in the learning process. Material is the material used in the implementation of learning to achieve learning objectives (Arifin, Nura'eni, \& Pranata, 2014). Material is curriculum content in the form of topics or subjects and details in learning. Psychowriting programs are expressive skills, so the material presented must be on target so that the objectives of learning writing materials can be achieved. The material developed in the psychowriting method must be considered in terms of its scope, type, and depth based on the situation and circumstances of the child. In selecting psychowriting learning materials, it is better if the material is related to local, regional, national and global issues, so that children have broad insights in understanding and responding to various situations.

Psychowriting learning media program is a tool in the form of a channel to convey messages or information from a source to the recipient. Media as a tool used to convey messages and information into teaching and learning activities to stimulate children's thoughts, feelings, attention and interests to increase effectiveness and efficiency in achieving learning goals (Nurmadiah, 2016; Tafonao, 2018). Media in the learning process of the psychowriting method has a function as a carrier of information from the source (psychowriter or teacher) to the recipient (child) (Alfi Syarihah \& Sodiq, 2018). The choice of media is very dependent on the learning material to be delivered. The media chosen is certainly the best media. In psychowriting, the selection of learning media is very flexible, which is clear that the event process can be fulfilled.

Psychowriting program evaluation, according to refers to the learning evaluation process, a process that determines the conditions, decisions where an objective can be achieved (Ahmadi, 2017). Learning evaluation can be interpreted as an effort that can be used as a reference to determine the success or failure of the psychowriting teaching and learning process. The domain of assessment must lead to three domains inherent in children in the psychowriting program, namely the realm of the thinking process (cognitive), the realm of attitude (affective), and the realm of skills (psychomotoric).

In general, the stages of implementing the psychowriting method which is carried out to improve linguistic intelligence in the area of children's writing interest, have six stages: a) preparation; b) memory strength test; c) presents the closest and fastest idea; d) creating an atmosphere; e) implementation of creative learning, and f) follow-up.

In the preparation stage, a high totality attitude must be possessed by both the teacher (psych writer) and the participant (child). This attitude must be built and even mutually building and motivating high. So that the hope of both parties, if the totality of the need for psychowriting has been built, total attention will also be awakened. In the memory ability test, several things can be used as references, by following this method it means that children get a big advantage, namely knowing the strength of memory and getting the closest idea in the theme of writing (Jayani \& Hastjarjo, 2011). For example, the participants are in such a way, holding blank paper and a pen. Then the children were guided to write down the nouns that were seen, or held, or seen and held, from waking up until they met the psych writer.

Children, without being allowed to talk to their peers, because the houses are different, the vehicles they ride are different, the roads they travel on are not the same, the food served at home is not the same, the children will think and write down the things they see and touch. For the last five hours. In 15-20 minutes, the children will compete, who gets how much, which is an interesting game. Psychowriters, before the action of writing nouns, generally give intervention to children to think chronologically by writing starting from whatever is in the bedroom, followed by whatever is in the bathroom, when congregational prayers go to the mosque to see anything, when breakfast, go to school when in the classroom, see the psych writer in the training room. This is to do a memory strength test or a memory strength test. Recall activities have a function in maintaining and retaining information in the short term and 
for transferring information from short-term memory into long-term memory. This repetition will be more effective with the support of reading and listening habits.

Tips that can be used in presenting the closest idea include reading, discussion, observation and recreational activities (Susilana \& Riyana, 2008). Get used to reading as much as possible, starting with things you like, of course; this will sharpen your brain to find interesting things. Then the discussion is held, sometimes it can also come up with interesting ideas. Carrying out observations or observations, either in the form of travelling or visiting the surrounding environment, this can provoke us to discover new things.

By implementing the psychowriting method, psychowriters can basically relate to the games played in the memory strength test. In the memory test, the children wrote the number of nouns. Of course, you will find a varied number of all the children who follow. Maybe someone got 50 words, 100 nouns, 200 nouns, or some even up to 400 nouns. This shows that everyone has their own memory power. The stage of determining the closest idea, if children find the closest idea, it will flow more easily in the development of the written strands. The next step, after holding the memory strength test event, which was then intervened with the participants was to find and determine the closest idea. In the mood creation, it is explained that the mood is not awaited, but must be created, and to maintain the atmosphere, the mood must be maintained so that it remains good so that it can become a productive writer.

At the time of psychowriting intervention, psych writer will direct children to develop their writing. The resulting work can be in the form of poetry, essays, short stories or anything that has been mutually agreed upon. The children look for and occupy a location that fits the mood, within the time specified in the intervention, the children will get steady and meaningful writing, because they have followed a long psychowriting process. The follow-up of the psychowriting method is to evaluate and follow up on the students' writing. The evaluation of the psychowriting program implements oral and written evaluations by taking scores in the form of authentic assessment evaluations. Psychowriters use the authentic assessment method according to one of the assessment methods in learning. The authentic assessment is in the form of a performance appraisal that reflects how children learn. This aspect of the final assessment is outlined in the assessment criteria that have been prepared. The evaluation time is carried out at the beginning of the lesson, in the learning process and at the end of the learning process.

Based on observations and testimonials given by the children supported by interviews with companions, the results of this study indicate that the psychowriting method can change the child's perspective. There are at least two benefits that children get after following the psychowriting method. First, writing activity is not a difficult job. Each participant, based on the results of the collected writings, observations, and testimonials, shows that they can become a writer. Second, publishing a book does not have to wait old. Since I was a child, he was able to publish books. Thus, the hypothesis in this study proved that the psychowriting method was able to improve linguistic intelligence in the field written for children.

\section{Conclusions and Suggestions}

Based on the discussion, it was found that writing activity is basically not difficult, by writing can reconstruct thoughts and feelings, so that the subject can express what is in writing. Psychowriting is a holistic method with a multidimensional approach to good creative learning. So the conclusion of the research focus is on the steps to implement psychowriting methods to improve linguistic intelligence in the field of writing for children, there are six steps, namely: a) preparation, b) memory strength test, c) presenting the closest and fastest idea, d) creating a mood (mood), e) implementation of creative learning and f) follow-up.

Suggestions in the next research are that it is necessary to anticipate the factors inhibiting children's interest in writing, including a) Stagnant ideas, namely there is a desire to write, but 
when the idea is put into practice, the idea does not work, so it stops; b) Time allocation, namely the obstacle faced by children is the absence of time allocated specifically for writing and producing written works; c) Language, namely the use of Indonesian as a written language to some extent makes children feel constrained because everyday language is used mostly in the mother tongue (regional language).

\section{References}

Ahmadi, A. (2017). Prototipe integrative writing model (IWM) berbasis psychowritingmyers-briggs type indicators (MBTI) dalam pembelajaran menulis. Inovasi-Jurnal Diklat Keagamaan, 11(1), 43-56.

Ahmadi, A., Sodiq, S., Setiawan, S., Pratiwi, Y., \& Hariyati, N. R. (2019). Learning Writing through Psychowriting Perspective. Advances in Language and Literary Studies, 10(1), 4-8.

Alfi Syarihah, N., \& Sodiq, S. (2018). Pengembangan Media Video Animasi dalam Pembelajaran Menulis Teks Eksplanasi Berbasis Psychowriting Kelas VIII B MTs Ihyaul Ulum Dukun, Gresik. Bapala, 5(2).

Arifin, N. N., Nura'eni, E., \& Pranata, O. H. (2014). Peningkatan pemahaman siswa terhadap materi geometri melalui pembelajaran berbasis teori Van Hiele. PEDADIDAKTIKA: Jurnal Ilmiah Pendidikan Guru Sekolah Dasar, 1(2), 96-102.

Barak, A., \& Miron, O. (2005). Writing characteristics of suicidal people on the Internet: A psychological investigation of emerging social environments. Suicide and LifeThreatening Behavior, 35(5), 507-524.

Castles, A., Rastle, K., \& Nation, K. (2018). Ending the reading wars: Reading acquisition from novice to expert. Psychological Science in the Public Interest, 19(1), 5-51.

Dlouhá, J., Barton, A., Janoušková, S., \& Dlouhý, J. (2013). Social learning indicators in sustainability-oriented regional learning networks. Journal of Cleaner Production, 49, 64-73.

Ernis, P. (2019). HUBUNGAN MINAT BELAJAR DENGAN KETERAMPILAN MENULIS PUISI SISWA KELAS X BUSANA 3 SMK NEGERI 3 PAYAKUMBUH. Ensiklopedia of Journal, 2(1).

Fitriani, Y. (2014). Model Pembelajaran seni musik melalui lesson study: studi kasus di SDN Jawilan, Serang. Resital: Jurnal Seni Pertunjukan (Journal of Performing Arts), 15(2), $126-138$.

Gardner, H. (2006). The development and education of the mind: The selected works of Howard Gardner. Routledge.

Group, W. B. (2016). Programme for International Student Assessment 2015. Europe and Central Asia.

Jasni, M., \& Atmazaki, A. (2020). Kontribusi Kebiasaan Membaca dan Motivasi Belajar terhadap Keterampilan Menulis Teks Eksposisi Siswa Kelas VIII SMP Pembangunan Laboratorium UNP. Pendidikan Bahasa Indonesia, 8(3), 231-237.

Jayani, S., \& Hastjarjo, T. D. (2011). Pengaruh Frekuensi Pemberian Tes Terhadap Memori 
Jangka Panjang Bacaan Pada Siswa SMA. Jurnal Psikologi Tabularasa, 6(2).

Komaladewi, A. T., \& Rodiyana, R. (2020). MENULIS KARANGAN NARASI DENGAN MODEL KNOW, WANT, LEARNED DI SEKOLAH DASAR. In Prosiding Seminar Nasional Pendidikan (Vol. 2, pp. 331-339).

Laila, I., \& SODIQ, S. (2018). Pengembangan Media Buku Permainan Labirin Fantasi (Buperlafa) dalam Pembelajaran Menulis Cerita Fantasi Berbasis Psychowriting Kelas VII SMP. Bapala, 5(2).

Mantasiah, R., Juffri, J., \& Yusri, Y. (2017). Keefektifan Model Pembelajaran Jaring LabaLaba (Webbed) dalam Keterampilan Menulis Karangan Sederhana Bahasa Jerman. Indonesian Journal of Educational Studies, 20(2).

Maryani, N., Ichsan, M., \& Khairunnisa. (2017). Signifikansi Metode Guide Reading Terhadap Motivasi Belajar Siswa Dalam Teori Membaca Nyaring Guide Reading Method On Students' Learning Motivation In Reading Loudly Lesson. Didaktika Tauhidi: Jurnal Pendidikan Guru Sekolah Dasar, 4(2), 126-139.

Moran, S., \& Gardner, H. (2018). Hill, skill, and will: executive function from a multipleintelligences perspective.

Nadlir, M. (2013). Perencanaan pembelajaran berbasis karakter. Jurnal Pendidikan Agama Islam (Journal of Islamic Education Studies), 1(2), 338-352.

Nurdin, N. (2019). Urgensi Literasi Sains Dalam Meningkatkan Kompetensi Widyaiswara PAI BDK Aceh Di Era Millenial. Jurnal Pendidikan Sains Indonesia (Indonesian Journal of Science Education), 7(1), 55-63.

Nurmadiah, N. (2016). Media Pendidikan. Al-Afkar: Jurnal Keislaman \& Peradaban, 5(1).

Orr, K., Smith, B., Arbour-Nicitopoulos, K. P., \& Wright, F. V. (2020). The café talk: a discussion of the process of developing a creative non-fiction. Qualitative Research in Sport, Exercise and Health, 1-17.

Rampung, B. (2017). Masalah sosial dalam cerpen Kompas tahun 2012: deskripsi masalah, bentuk pengungkapan, dan relevansinya untuk pendidikan karakter. BIBLIOTIKA: Jurnal Kajian Perpustakaan Dan Informasi, 1(1), 1-20.

Riemer, V., Frommel, J., Layher, G., Neumann, H., \& Schrader, C. (2017). Identifying features of bodily expression as indicators of emotional experience during multimedia learning. Frontiers in Psychology, 8, 1303.

Shah, D. V. (2016). Conversation is the soul of democracy: Expression effects, communication mediation, and digital media. Communication and the Public, 1(1), $12-$ 18 .

Subandiyah, H. (2017). Pembelajaran literasi dalam mata pelajaran bahasa indonesia. Paramasastra, 2(1).

Susilana, R., \& Riyana, C. (2008). Media pembelajaran: hakikat, pengembangan, pemanfaatan, dan penilaian. CV. Wacana Prima.

Tafonao, T. (2018). Peranan media pembelajaran dalam meningkatkan minat belajar 
mahasiswa. Jurnal Komunikasi Pendidikan, 2(2), 103-114.

Wahyuni, R. (2017). Pengembangan Lembar Kerja Siswa Bahasa Indonesia Kelas X-7 Berdasarkan Pendekatan Psychowriting Kurikulum 2013 Implementasi 2016 Semester Genap SMA Negeri 13 Surabaya. Bapala, 4(1).

Wardiah, D. (2017). Peran Storytelling dalam Meningkatkan Kemampuan Menulis, Minat Membaca dan Kecerdasan Emosional Siswa. Wahana Didaktika: Jurnal Ilmu Kependidikan, 15(2), 42-56.

Wu, C., Cha, J., Sulek, J., Sundaram, C. P., Wachs, J., Proctor, R. W., \& Yu, D. (2020). Sensor-based indicators of performance changes between sessions during robotic surgery training. Applied Ergonomics, 90, 103251. 